\title{
Marka Değeri En Yüksek 100 Türk Markasının Sosyal Medya Kullanımları Üzerine Bir İnceleme
}

\author{
Kumru Uyar (Dr. Öğr. Üyesi) \\ Nuh Naci Yazgan Üniversitesi İktisadi ve İdari Bilimler Fakültesi \\ kuyar@nny.edu.tr \\ Orcid: 0000-0002-2604-5317 \\ Burcu Oralhan (Dr. Öğr. Üyesi) \\ Nuh Naci Yazgan Üniversitesi İktisadi ve İdari Bilimler Fakültesi \\ boralhan@nny.edu.tr \\ Orcid: 0000-0001-8905-0140 \\ İsmail Vefa Bayırbaş \\ vefabayirbas@yandex.com \\ Orcid: 0000-0002-8223-3654
}
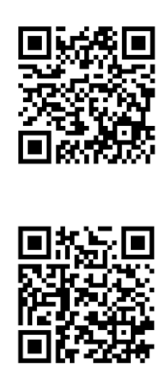

Başvuru Tarihi: 02.11.2018

Yayına Kabul Tarihi: 29.12.2018

Yayınlanma Tarihi: 21.01.2019

Öz

İşletmeler, kurumsal performanslarını geliştirmek ve şirketlerini dönüştürmek için sosyal medya teknolojilerine gittikçe daha fazla önem vermektedirler. Bu çalışma, sosyal medya takipçi sayıları ve marka değeri arasındaki ilişkiyi incelemektedir. Günümüzde önemi ve pazarlamaya olan katkısı yadsınamaz olan sosyal medya pazarlaması ile ilgili çok sayıda çalışma bulunmamaktadır. Ayrıca, marka değeri konusu, pazarlama yönetimi için en kritik alanlardan biri olarak ortaya çıkmıştır. Bununla birlikte, konuya yoğun ilgi gösterilmesine rağmen, sosyal medya faaliyetlerinin marka değerine etkilerinin ne olduğuna dair ampirik kanıt yoktur. Literatürde marka değeri ve firmaların sosyal medya takipçi sayıları arasındaki ilişkiyi inceleyen bir çalışmaya ulaşılamamıştır. Bu açıdan bu çalışma konuya yeni bir bakış açısı kazandıracaktır. Bu çalışmada, "Brand Finance" araştırma şirketinin 2017 yılında yayınladığı ve Türkiye'nin en değerli markalarını listelediği "Turkey100" raporunda yer alan 100 şirketin kurumsal sosyal medya hesaplarının incelenmesi ve bu şirketlerin sektörel anlamda sosyal medya kullanımındaki etkinlik derecelerinin belirlenmesi amaçlanmıştır. Çalışmada, bankacılık ve sigorta, gıda, otomotiv, teknoloji ve bilişim, spor, tekstil, inşaat, ulaşım ve enerji gibi çeşitli 13 ana sektörde faaliyet gösteren ve Turkey100 listesinde yer alan şirketlerin Türkiye merkezli kurumsal Facebook, Twitter, Instagram, Youtube, LinkedIn ve Pinterest hesapları ve bu hesaplardaki kullanıcı sayıları incelenmiştir. Elde edilen bulgulara göre araştırmaya konu olan şirketler arasında genel olarak en fazla kullanılan sosyal medya ağının Facebook olduğu görülürken en az kullanılan sosyal medya ağının Pinterest olduğu görülmüştür. Bulgular sektörel olarak incelendiğinde sektörün özelliklerinin ve pazarlama şekillerinin etkisiyle farklı sektörlerde farklı sosyal mecraların ön plana çıktığı sonucuna ulaşılmıştır.

Anahtar Kelimeler: Marka Değeri, Sosyal Medya, Sosyal Medya Pazarlaması, Turkey 100. 
Research Article

\title{
An Investigation on the Social Media Usage of the 100 Highest Brand Value on Turkish Brands
}

\author{
Kumru Uyar (Asst. Prof. Dr.) \\ Nuh Naci Yazgan University \\ Faculty of Economics and Administrative Sciences \\ kuyar@nny.edu.tr \\ Orcid: 0000-0002-2604-5317 \\ Burcu Oralhan (Asst. Prof. Dr.) \\ Nuh Naci Yazgan University \\ Faculty of Economics and Administrative Sciences \\ boralhan@nny.edu.tr \\ Orcid: 0000-0001-8905-0140 \\ İsmail Vefa Bayırbaş \\ vefabayirbas@yandex.com \\ Orcid: 0000-0002-8223-3654
}

Date Received: 02.11.2018

Date Accepted: 29.12.1018

Date Published: 21.01.2019

\begin{abstract}
Companies are increasingly advocating social media technologies to transform businesses and improve corporate performance. This study examines the relationship between social media followers and brand value. Nowadays, there are not many studies on social media marketing which has an important role and increasing contribution in marketing. In addition, the issue of brand value has emerged as one of the most critical areas for marketing management. Nevertheless, there is no empirical evidence of the effects of social media activities on brand value, although there is a strong interest in the issue. Besides, a study examining the relationship between brand value and number of social media followers has not been reached in the literature. In this respect, this study will give a new perspective to the subject. The aim of this study is to examine the corporate social media accounts report of 100 companies, which are in Turkey's list of most valuable brands "Turkey 100" published by "Brand Finance" research company in 2017, and to determine the degree of efficiency in the use of social media in sectoral sense of these companies. In the study, corporate Facebook, Twitter, Instagram, Youtube, LinkedIn and Pinterest accounts and the number of users in these accounts of the companies, which are in "Turkey 100" list and operating in 13 major sectors such as banking and insurance, food, automotive, technology and information, sports, textile, construction, transportation, are examined. According to the findings, it is seen that the most widely used social media network is Facebook, while the least used social media network is Pinterest among the companies surveyed. When the findings are analyzed in terms of sector, it is concluded that different social media have come to the forefront in different sectors due to the characteristics of the sector and marketing forms.
\end{abstract}

Keywords: Brand Value, Social Media, Social Media Marketing, Turkey 100. 


\section{Giriş}

İnternette web 2.0 altyapısının gelişmesi sosyal medyada karşılıklı etkileşimleri mümkün hale getirmiştir. Bu gelişmeile sosyal medya platformlarının popülaritesinde ve kullanıcı sayılarında büyük bir artış meydana gelmiştir. Böylece pek çok alanda olduğu gibi pazarlama alanında da sosyal medyaya olan ilgi artmıștır. Günümüzde sosyal medya firmaların pazarlama faaliyetlerinde etkili bir iletişim aracı olarak aktif bir biçimde kullanılmaktadır. Sosyal medyada pazarlama faaliyetlerini geleneksel pazarlama faaliyetlerinden çok daha az çaba ve maliyetle gerçekleștirmek mümkündür. Literatürde marka ve sosyal medya pazarlaması kavramları farklı boyutlarıyla pek çok çalışmada ele alınmıştır. Ancak, takipçi sayıları ile marka değeri arasındaki ilişkiyi inceleyen bir çalışmaya rastlanılamamıştır. Marka ve müşteri arasındaki ilişkinin güçlü olması ürün ve markanın gelişimini destekler (Huang ve Benyoucef, 2015, 72). Dolayısıyla, en yeni iletişim kanalı olan sosyal medyada firmaların müşterileri ile kurdukları iletişimin etkinliğinin de marka değerini etkilemesi beklenmektedir.

Bu çalışmada, 2017 yılında yayınlanan Türkiye'nin en değerli 100 markasının kurumsal sosyal medya hesaplarının kullanımındaki etkinlik derecelerinin belirlenmesi amaçlanmıştır. Çalışmada, 13 ana sektörde faaliyet gösteren en değerli 100 şirketin Türkiye merkezli kurumsal sosyal medya hesapları ve bu hesaplardaki kullanıcı sayıları incelenmiştir. Çalışmanın birinci bölümünde marka değeri kavramı ve işletmeler için önemi, ikinci bölümünde sosyal medya pazarlaması, sosyal medya platformlarının özellikleri ve bu medyaların tüketicileriyle iletişimlerinde firmaya katkıları değerlendirilmiştir. Üçüncü bölüm çalışmanın amacı doğrultusunda yapılan literatür araştırmasını içermektedir. Dördüncü bölümde araştırmanın yöntemi açılklanmıştır. Çalışmada sosyal medya hesaplarından toplanan veriler SPSS 22 kullanılarak analiz edilmiştir. Değişkenler arasındaki ilişkileri tespit edebilmek için korelasyon, gruplar arasındaki farklılıkları tespit edebilmek için Tek Yönlü Varyans (ANOVA) ve marka değeri üzerinde takipçi sayılarının etkisini belirleyebilmek için regresyon analizleri kullanılmıştır. Araştırmanın son bölümlerinde ise gerekli analizler yapılarak bulgular paylaşılmış ve sonuç kısmında bunlara yönelik değerlendirmeler yapılmıștır.

Araştırmanın iki temel kısıtı vardır. Bunlardan ilki araştırmanın örnekleminin Brand Finance şirketinin yayınladığı en değerli markalar listesinde yer alan firmalarla sınırlandırılmasıdır. İkincisi ise sosyal medya faaliyetlerinin sadece takipçi sayıları açısından ele alınmasıdır. Ancak bu çalışma literatüre getirdiği yeni bakış açısıyla marka değeri ve sosyal medyanın gücü konusunda üst düzey yöneticiler için yeni anlayışlar ortaya koyacaktır.

\section{Marka Değeri}

Marka değeri, işletmeler için son derece önemli bir kavram olmasına rağmen 1980'lere kadar firmalar tarafından önemsenmemiştir. Bu nedenle birçok şirket markalarının gerçek değerini bilançolarına yansıtamamıştır. Marka değerini şirketin mali olarak değerlemesi ve finansal tablolarına dahil etme eğilimi 1980'lerde ABD'de başladı ve günümüzde dünya çapında giderek daha da önemi arttı (Salinas ve Ambler, 2009). Haigh ve İlgüner'in belirttiği gibi $(2012,41)$ marka değerlendirmeyi gündeme getiren en önemli gelişme bu yıllarda yaşanan şirket ele geçirme akımıdır. 1980'lerde işletmeler arasında birleşme ve devralmaların artmasıyla birlikte, 
marka değeri konusu iş dünyasının ve akademisyenlerin dikkatini çekmiştir. Kısaca markanın finansal getirisi olarak tanımlayabileceğimiz marka değeri hem finansal hem de tüketici düzeyinde firmaya etkilerde bulunur. Marka değeri Simon ve Sullivan (1993)'ün belirttiği gibi firma düzeyinde, yatırımcıların ve finansal analistlerin algısını etkiler ve firmaların hisse senedi fiyatlarının belirlenmesinde rol oynar. Ayrıca tüketici düzeyinde, satın alma amacı da dahil olmak üzere davranışsal sonuçları olumlu yönde etkilemektedir (Cobb-Walgren ve diğerleri, 1995). Marka değeri kavramının öneminin kavranmasıyla firmalar güçlü markalar yaratmak için çaba harcamaya başlamıștır.

Aaker $(2001,165)$ marka değerini “bir işletme veya işletmenin müșterileriyle ilișkili olarak, mal ve hizmetlerle sağlanan değere eklenen veya o değerden çıkarılan, markayla, marka ismiyle veya sembollerle ilişkili varlık ve yükümlülüklerdir" şeklinde tanımlamaktadır. Bir markanın kimlik haklarının parasal değeri, belirli bir zaman diliminde pazardan elde edeceği gelir şayet varsa menkul kıymetler yelpazesinde yer alan enstrümanların finansal karşılığı, o markanın değeri olarak nitelenebilir (Pelsmacker ve diğerleri, 2001'den Aktaran: Tosun, 2014, 257). Marka değeri, ortalama bir marka ile karşılaştırıldığında, güçlü bir markanın satılması ile ödenecek fiyat değeridir (Baldauf ve diğerleri, 2003, 221).

Marka değerinin hesaplanmasında araştırma amacı ve araştırmacının uzmanlık alanına göre farklı yaklaşımlar uygulanmaktadır. Bu nedenle, teorik olarak henüz marka değeri hesaplanmasıyla ilgili tek bir ortak yöntem oluşmamıştır. Mevcut literatürde marka değeri üç şekilde tanımlanarak hesaplanmaktadır. Bunlar finansal anlamda, tüketici temelli ve karma yöntemler şeklindedir. Pek çok çalışmada marka denkliğinin çeşitli finansal tekniklerle ölçülmesine odaklanılmıştır. (Farquhar ve diğerleri, 1991; Kapferer, 1997; Simon ve Sullivan, 1993; Swait ve diğerleri, 1993). Finansal yöntemler, finansal tablolardaki verilerin kullanılarak marka değerinin tespit edildiği yöntemlerdir. Finansal anlamda marka değeri, marka tarafından bir varlık olarak yaratılan işletme için mali fayda olarak yorumlanabilir (Huang, 2015, 72). Finansal yöntemler içinde en çok kullanılan yöntemler; maliyete dayalı yöntemler ve gelir esasına dayalı yöntemdir (Özkan ve Terzi, 2012, 87). Son yıllarda yapılan çalışmalarda ise, marka denkliği, giderek daha fazla müşteri temelli olarak tanımlanmaktadır (Keller, 1993; Yoo ve diğerleri, 2000). Tüketici temelli yöntemde müșteri bakıș açısı ile marka denkliği tanımlanır ve Aaker (1991) ve Keller (1993)'in tüketici tabanlı marka denkliği kavramlaştırmasına dayanır. Müşterilerin bakış açısıyla yapılan araştırmalar, marka değerinin nicel değerlendirmesi için bir temel oluşturur. Markanın değerini tanımlamak için marka denkliği kullanılır (Jones, 2005, 14). Marka denkliği tüketicilerin gözünde markanın değeridir. Marka denkliği marka değerini arttırabilir. Marka denkliği, bir markanın müşterinin gözünde taşıdığı önemi ifade ederken marka değeri, markanın taşıdığı finansal önemdir. Hem marka değeri hem de marka denkliği, bir markanın kıymetini belirlemede etkilidir. Karma yöntemler ise marka değerini hem varlık hem de müşteri temelli bir bakış açısıyla tanımlarlar. Bu yöntemler finansal ve finansal olmayan verileri bir arada kullanmaktadır.

Marka değeri, işletmeleri pazarda yüksek bir yere çıkaran aynı zamanda ürünlerine rakiplerinden daha yüksek fiyatlandırma olanağı sunan bir güç olarak ifade edilmektedir (Aaker, 1992). Tüketicilerin marka bilinirliği/farkındalı̆̆ı, marka çağrışımları, algılanan kalite, marka bağlılığı ve diğer marka varlık boyutlarına 
yansıdığı gibi bir markayla ilişkilendirdiği değerdir. Marka denkliği, marka tarafından yönetilen mevcut veya potansiyel bir ürün veya hizmetin değerini arttıran veya azaltan marka bilinirliği/farkındalı̆̆ı, marka çağrışımları, algılanan kalite, marka bağlılığı gibi bir dizi varlık veya yükümlülüktür. Marka denkliği, markaların sadece kısa vadeli satış üreten taktiksel bir unsur olmayıp, uzun vadede işletmeye değer katan stratejik bir destek olduğunu ortaya koymuştur. Böylece marka değeri konusundaki algı değișmiștir. Diğer taraftan marka değeri, markanın finansal değeridir. Tüketici temelli marka denkliğinde gerçekleşebilecek herhangi bir değișme markanın değerini de etkileyebilecektir.

Marka değerini hem varlık hem de müşteri temelli bir bakış açısıyla tanımlayan karma yöntemlerden biride bir marka danışma şirketi olan Brandfinance'in farklı ülkelerde en değerli markaları tanımlamak için yaptığı hesaplamadır. Brandfinance tüketici odaklı yerine iş odaklı bir tanımlama yapmaktadır. Brand Finance sıralama tablolarında yer alan markaların değerlemesinde "Hak Bedeli" yaklaşımını kullanmaktadır. Bu yaklaşım markaya ait gelecekteki satışları ve bu satışlara yüklenecek markanın kullanımında doğan bir hak bedelini içermektedir. Brandfinance her yıl "National Brand Index" çalışması ile ülke markalarını incelemektedir.

\section{Sosyal Medya Pazarlaması}

Sosyal medya, etkileşimleri, işbirliklerini ve içerik paylaşımını kolaylaştırmayı amaçlayan çevrimiçi uygulamalar, platformlar ve medyadır. Alexander'ın (2006, 33-34) belirttiği gibi web 2.0 teknolojisi, kullanıcıların aktif bir şekilde internet ortamında yer almalarına olanak sağladığı için literatürde sosyal medya kavramı, web 2.0 teknolojisinin gelişmesi ile anılmaya başlamıştır. Kaplan ve Haenlein, (2010) sosyal medyayı, “Web 2.0'ın ideolojik ve teknolojik temelleri üzerine inşa edilen, kullanıcı tarafından içeriğin oluşturulmasına ve değiştirilmesine izin veren bir grup İnternet tabanlı uygulama" olarak tanımlamaktadır. Bu tanımdan da anlaşılacağı gibi sosyal medya, bir uygulamalar platformu olan Web 2.0 altyapılarını kullanan iletişim araçlarının bütününe verilen addır. Bu sebeple sosyal medya kavramını etkili olarak tanımlayabilmek için Web 2.0 kavramını açıklamak gerekmektedir. Web 2.0 ilk kez 2004 yılında "Dünya Çapında Ağ"dan faydalanmak amacıyla yazılım geliştiricilerinin ve son kullanıcıların daha aktif olduğu platformları tanımlamak için kullanılmıștır. Web 1.0'da kullanıcılar tek taraflı ve az sayıdaki web sitesine erişebiliyorken Web 2.0 ile birlikte kullanıcılar, sürece dâhil olarak daha çok siteye erișebilmekte ve süreçte aktif rol alarak kullanıcıların birbiri ile olan etkileşimleri artmaktadır (Güler, 2015, 192). Sosyal medya geleneksel tek yönlü iletişimi çok boyutlu ve iki yönlü iletişim haline dönüştürmüştür (Berthon ve diğerleri, 2012).

Safko $(2010,33)$ 'ya göre sosyal medya işletmelerin, mevcut ve hedef pazarlara ulaşmak için kullandıkları sosyal platformlardır. Pazarlama alanında ise sosyal medya, kullanıcıların etkin rol alması sebebiyle "tüketici tarafından oluşturulan medya” olarak ifade edilmektedir (Mangold ve Faulds, 2009, 357). Sosyal medya, katılımcllık ve ortak hareket etme özelliklerinin internete uyarlanması olarak ifade edilmiştir (Constantinides ve Fountain, 2008, 232-233). Bu mecra şu anda kullanıcıların çevrimiçi zamanlarının neredeyse dörtte birini karşılamaktadır, bu da oyun ve e-postayı fazlasıyla aşmaktadır (Gallaugher ve Ransbotham, 2010). Tüketiciler bilgi aramak ve geleneksel medyadan uzaklaşmak için sosyal medya sitelerini giderek daha fazla kullanmaktadırlar (Mangold ve Faulds, 2009). 
Son yüzyılda pazarlamada, tüketiciler ve piyasalarda teknolojik gelişmelerin de etkisiyle önemli değişimler meydana gelmiştir (Kotler, 2010, 17). Sosyal medyanın çok yönlü olması ve çeşitli amaçlarla kullanılabilmesi, sosyal medyanın hem en belirgin özelliği hem de sahip olduğu en büyük avantajıdır. Sosyal medya vasıtasıyla dünya genelinde bağlantı kurulabilmekte ve erişilebilirlik sağlanmaktadır (O'Keeffe ve Clarke-Pearson, 2011, 801). Böylelikle küresel dünyada bireyler ve firmalar coğrafi veya fiziki engellere takılmadan iletişim sağlayabilmektedir. Kullanıcı sosyal medya üzerinden dünyanın neresinde olursa olsun birçok unsura rahatça ulaşabilmektedir (Yates ve Paquette, 2011, 7). Sosyal medyanın, eş zamanlı medya paylaşımını desteklemesiyle birlikte işletmeler, farklı coğrafi bölgelerde olsalar dahi aynı yerdeymiş gibi iletişim kurabilmektedir (Rowlands ve diğerleri, 2011, 184). Bu durum bir bakıma tüketici ve üretici arasındaki ilişkilerin güçlendirilmesinde büyük faydalar sağlamaktadır.

Sosyal medya kanalları tüketiciler tarafından marka ve ürünlere ilişkin bilgileri aramak için giderek daha fazla kullanılmaktadır (Mangold ve Faulds, 2009; Bambauer-Sachse ve Mangold, 2011). Bu platformlar aracılığı ile işletmeler daha geniş kitlelere, daha ucuza erișebilmektedir. Sosyal medya "kalabalığın gücünü" yakalar. Sosyal medyada farklı profillerde insanların bulunması işletmeler için pek çok firsat yaratmıştır. İşletmeler sosyal medyanın barındırdığı ortak ilgi grupları aracılığıyla ise tüketici gruplarına kolay ve geniş çapta ulaşılabilmektedir. Özellikle sosyal medyanın gelişmesi ve çevrimiçi paylaşımlarla ulaştığı kitleler ile sosyal medya platformları firmalar için önemli pazarlama mecraları haline gelmiştir. Şirketler sosyal medya ile iş dünyasını dönüştürmeyi ve finansal değerden yararlanmayı hedeflemektedir (Divol ve diğerleri, 2012). Yöneticiler için, sosyal medya platformları müşteri ilişkilerini, marka varlıklarını ve iş süreçlerini yönetmek açısından iş dönüşümünü kolaylaştırabilir. (Luo ve diğerleri, 2013, 146). Sosyal medya pazarlaması; çevrimiçi sosyal ağlar aracılı̆̆ı ile firmaların ürünlerini ve markalarını tanıtmalarına ve büyük topluluklardan istifade ederek onlarla sürekli iletişim kurabilmelerine olanak sağlayan bir süreç olarak tanımlanabilmektedir. Vinerean ve diğerleri, $(2013,68)$ 'nin belirttiği gibi sosyal medya üzerinden firma hedef müşteri ile doğrudan bağlantı ve ilişki kurabilmektedir. Sosyal medyada yer alarak firmalar, görünürlüklerini arttırarak, faaliyetlerini daha geniş kitlelere duyurarak mal ve hizmetlerini tutundurma imkânına kavuşurlar. Şirketler, kurum ve kuruluşlar, sosyal medya platformu içerisinde kendi siteleri ile bağlantılı sosyal medya hesapları oluşturmaktadır. Böylelikle bu kurumlar kendisini topluma ve müşteri kitlesine daha rahat ifade ederek kurumsal kimliğini sosyal medya kimliği ile birleştirmektedir (Gensler ve diğerleri, 2013, 246).

Sosyal medya platformlarında yer alan firmalar, tüketicileri ile çok daha demokratik, katılımcı, tüketici odaklı hem birebir hem de kitlesel olarak iletişim kurabilmektedir. Markaların tüketiciler tarafından algılanan sosyal medya pazarlama aktiviteleri, eski moda pazarlama performanslarına göre farklı değerler içermektedir (Kim ve Ko, 2012, 1484). Günlük olarak milyonlarca paylaşımın yapıldığı Facebook, Instagram gibi sosyal medya platformları birçok firma için ürün ya da hizmetlerini pazarlayabilecekleri devasa bir pazar yeridir. Sosyal medyanın karşılıklı iletişimlere, alınan mal veya hizmetlere yönelik yorumlara ve geribildirimlere açık olması pazarlamacılar açısından son derece önemlidir (Kara, 2012, 110). Sosyal medyada içeriğin büyük bir bölümünü kullanıcılar 
oluşturmaktadır. Sosyal medya platformları, müşterilerin diğer tüketicilerle etkileşime geçmesi için bir fırsat sunmaktadır. Bu nedenle, şirketler artık marka iletişiminin tek kaynağı değildir (Li ve Bernoff, 2011). İşletmeler, ürün ve marka sadakati oluşturmak için sosyal medyada ürün ve markaları etrafında topluluklar kurmaya çalışmaktadırlar (Huang ve Benyoucef, 2013).

Sosyal medya platformlarında iletişim, görsel, yazılı veya anlık olup olmaması gibi faktörlere göre farklı düzeylerde gerçekleşebilmektedir (Wang ve diğerleri, 2010, 20). Twitter 'da iletişim kısa mesajla ve karakter sınırı ile gerçekleşirken "Second Life" gibi sanal dünyalarda yazıll, görsel ve sesli iletişim kurarak iletişim sağlanabilmektedir. Blog tarzı uygulamalarda ise kısa ve anlık iletişimden ziyade daha uzun ve sürekli iletişim kurulması mümkündür. Bu sebeple işletmeler, amaçlarına göre bazı sosyal medya uygulamalarını diğerlerine kıyasla daha çok tercih edebilmektedir (Lariviere ve diğerleri, 2013, 271). İşletmeler; yeni ürünlerini, uygulamalarını ve kampanyalarını sosyal medya platformları aracılığıyla hedef kitleleri ile paylaşabilmektedir (Goh ve diğerleri, 2013, 88). Bu kapsamda ticari organizasyonlar, kampanya veya reklamlarına dair yazı, fotoğraf, video, link ve konum gibi bilgileri içeren paylaşımlarda bulunmaktadır. Bu sayede şirketler, hedef müşteri kitlelerine yönelik içerikleri tek seferde paylaşabilmektedir. Hedef müșteri kitlesine ulaşmak isteyen şirket ve kuruluşlar da yeni bağlantı oluşturabilecekleri, müşterilerle daha yakından ilișki kurabilecekleri sosyal medya uygulamalarını daha çok tercih etmektedir (Yücel, 2013, 1647).

Sonuç olarak markalar zamanla sosyal medyayı, hedef tüketicileri ile doğrudan iletişim kurabilecekleri, marka tanınırlığını arttırabilecekleri ve yeni ürünlerini sergileyecekleri ucuz ve kolay potansiyel pazarlama kanalları olarak görmeye başlamıştır.

\section{Literatür Araştırması}

Sosyal medya faaliyetlerine işletmelerin bütçe aktarımını kolaylaştırabilmek için, sosyal medyanın yarattığı değerlerin ölçülmesi gerekir. Gao ve Hitt (2012) bilgi teknolojilerini kullanmanın ürün çeşitliliği arttırma yönündeki olumlu etkisiyle ticari marka sahiplerine daha yüksek katkıda bulunduğunu tespit etmişlerdir. Sosyal medya ölçütleri, yatırımcıların yalnızca firmanın müşteri duyarlılığını ve marka performansını izlemesine değil, aynı zamanda gelecekteki iş değerini de tahmin etmesine izin verebilir. Luo ve diğerleri'ne göre sosyal medya yatırımcıları gelecekteki performans beklentileri hakkında en güncel bilgilerle donattığı için, firma öz sermaye değerinin önde gelen göstergesi olarak hizmet edebilir $(2013,146)$.

Önceki çalışmalar sosyal medya kullanıcı ölçümleri ile ürün satışları arasındaki ilişkiyi (Chevalier ve Mayzlin, 2006; Dellarocas ve diğerleri, 2007; Dhar ve Chang, 2009; Ghose ve Yang, 2009; Moe ve Fader, 2004), çevrimiçi tüketici derecelendirmelerinin ürün tercihi ve satın alma kararına etkisi (Chevalier ve Mayzlin, 2006; Dellarocas ve diğerleri, 2007; Duan ve diğerleri, 2008; Godes ve Mayzlin, 2004; Liu 2006; Zhu ve Zhang, 2010) blogların satışlar üzerindeki etkisi (Aggarwal ve diğerleri, 2012; Dewan ve Ramaprasad, 2012; Dhar ve Chang, 2009; Droge ve diğerleri, 2010) incelemektedir. Görüldügü gibi geçmiş literatürde sosyal medya ve satışlar arasındaki ilişki üzerinde durulmuştur. Literatürde tüketici sosyal medya algısının marka denkliği üzerindeki etkilerini inceleyen çalıșmalar yer almaktadır (Bruhn ve diğerleri, 2012; Gümüş ve diğerleri, 2013; Kim ve Ko, 2012; Schivinski, 2013; Schivinski ve Dabrawski, 2014). 
Marka değerini tüketici temelli olarak ele alan Cobb-Walgren ve diğerleri, (1995) çalışmalarında daha yüksek denkliğe sahip markaların daha çok tercih edildiği ve daha yüksek satın alma niyeti oluşturduğunu tespit etmişlerdir. Kim ve Ko (2012) ise sosyal medya pazarlama faaliyetlerinin lüks moda markalarında tüketici temelli marka denkliği üzerindeki etkilerini incelemişlerdir. Araştırmalarında, markaların ve müşterilerin zaman, mekan ve ortamdan bağımsız olarak birbirleriyle iletişim kurmasını, böylece eski moda tek yönlü iletişim yöntemi yerine doğrudan, interaktif ve iki yönlü iletişim kurulması gerektiğini tespit ettiler. Çalışmalarında, sosyal medya pazarlama faaliyetlerinin, marka denkliği üzerinde olumlu etkileri olduğunu tespit etmişlerdir. Schivinski ve Dabrawski (2014) kullanıcı tarafından oluşturulan sosyal medya iletişiminin marka denkliği üzerinde olumlu bir etkiye sahip olduğunu gösterir. Kazancı ve Başgöze (2015) sosyal medya algısının; marka kredibilitesi, marka prestiji ve satın alma eğilimini olumlu ve anlamlı yönde etkilediğini tespit etmişlerdir. Tüketicilerin, bir ürün ya da markaya ilişkin sosyal medya araçlarını kullanımının satın alma niyeti üzerinde olumlu bir etkiye sahip olduğu ortaya konulmuştur (Berger ve diğerleri, 2012; Hayta, 2013). Ancak, yazarların ulaşabildiği kadarı ile sosyal medya takipçi sayılarının marka değeri üzerine etkilerinin incelendiği bir çalışmaya erişilememiştir. Önceki çalışmalardan farklı olarak, bu çalışma sosyal medya takipçi sayılarının marka değeri ile nasıl bir ilişkisi olduğunu ortaya koymayı amaçlar. Marka değerinin bu şekilde sosyal medya ile bağlantılı olarak incelenmesi konuya yeni bir bakış açısı getirebilir. Özellikle, bu çalışma "Sosyal medya, sosyal medya hesaplarındaki takipçi sayıları ile firma değeri arasında anlamlı bir ilişki var mı?" şeklinde oluşturulan araştırma sorusunu cevaplamayı amaçlamaktadır.

\section{Araştırmanın Yöntemi}

Günümüzdegiderekönemiartan sosyal medyadayürütülen faaliyetlerin marka değeri üzerinde etkisi olup olmadığı önemli bir konudur. Araştırmamızda, Brand Finance araştırma şirketinin Türkiye'nin en değerli markalarını listelediği "Turkey100 2017" raporunda bulunan 100 şirketin sosyal medya kullanımları incelenmiştir (Brand Finance, 2017). Söz konusu şirketlerin sosyal medya platformlarındaki resmi hesapları dikkate alınmış ve bu hesaplardaki takipçi sayıları tespit edilmiştir. $\mathrm{Bu}$ firmaların sosyal medya kullanım tercihleri ve oranları sektörel olarak analiz edilmiştir. Sosyal medyanın aktif olarak kullanımı sebebi ile takipçi sayıları her an değişiklik gösterebilmektedir. Bu araştırmada 2017 yılı Aralık ayı (20.12.2017 28.12.2017 tarih aralığında gerçekleşen) takip sayıları esas alınmıştır.

\section{Araştırmanın Bulguları}

Brand Finance-Türkiye tarafından yayınlanan “TURKEY100 - Türkiye'nin En Değerli Markaları" araştırmasının sonuçlarına göre Türk Telekom A.Ş. 2.620 milyar dolar marka değeri ile Türkiye'nin en değerli markası olarak saptanmıştır. İkinci en değerli marka 1.959 milyar dolar değer ile Turkcell'dir, ve 1.920 milyar dolar marka değeri ile Türk Hava Yolları üçüncü sırada yer almıştır. Çalışmada yer alan en değerli 100 firma belirlenen 12 temel sektör ve 1 diğer sektör olacak şekilde, toplam 13 sektör altında gruplanmıştır.

Toplam değerin \%34,91'i bankacılık ve finans sektörü, \%16,84'ü telekomünikasyon sektörü, \%13,51'i gıda sektörü tarafından oluşturulmaktadır. Türkiye'nin en değerli yüz markasının toplam değeri 27.404 milyar dolardır. Tablo 1'de sektör gruplarının marka değeri dağılımı yer almaktadır. 
Tablo 1: Sektörlerin Marka Değeri Dağılımı

\begin{tabular}{|l|c|c|c|}
\hline SEKTÖR GRUP & $\begin{array}{c}\text { Toplam Marka } \\
\text { Değeri (USDm) }\end{array}$ & Sektör \% & $\begin{array}{c}\text { Ortalama Marka } \\
\text { Değeri (USDm) }\end{array}$ \\
\hline Bankacılık ve Finans & 9.567 & 34,91 & 415,96 \\
\hline Dayanıkı Tüketim & 2.266 & 8,27 & 566,50 \\
\hline Diğer & 763 & 2,78 & 152,60 \\
\hline Gıda & 3.702 & 13,51 & 217,76 \\
\hline İnşaat ve İnşaat Malzemeleri & 447 & 1,63 & 74,50 \\
\hline Otomotiv ve Otomotiv Yan Sanayi & 1.777 & 6,48 & 148,08 \\
\hline Perakende - Ev Geliştirme & 129 & 0,47 & 43,00 \\
\hline Perakende-Akaryakıt & 416 & 1,52 & 208,00 \\
\hline Spor Küübü & 337 & 1,23 & 84,25 \\
\hline Teknoloji-Bilişim-Dağıtım & 237 & 0,86 & 39,50 \\
\hline Tekstil ve Hazır Giyim & 669 & 2,44 & 74,33 \\
\hline Telekomünikasyon & 4.615 & 16,84 & 1538,33 \\
\hline Ulaşım ve Lojistik & 2.482 & 9,06 & 413,67 \\
\hline Genel Toplam & 27.407 & 100 & 274,07 \\
\hline
\end{tabular}

Türkiye'nin en değerli yüz markasının 23 tanesi bankacılık ve finans, 17 tanesi gıda ve 12 tanesi otomotiv ve otomotiv yan sanayi sektöründe faaliyette bulunmaktadırlar.

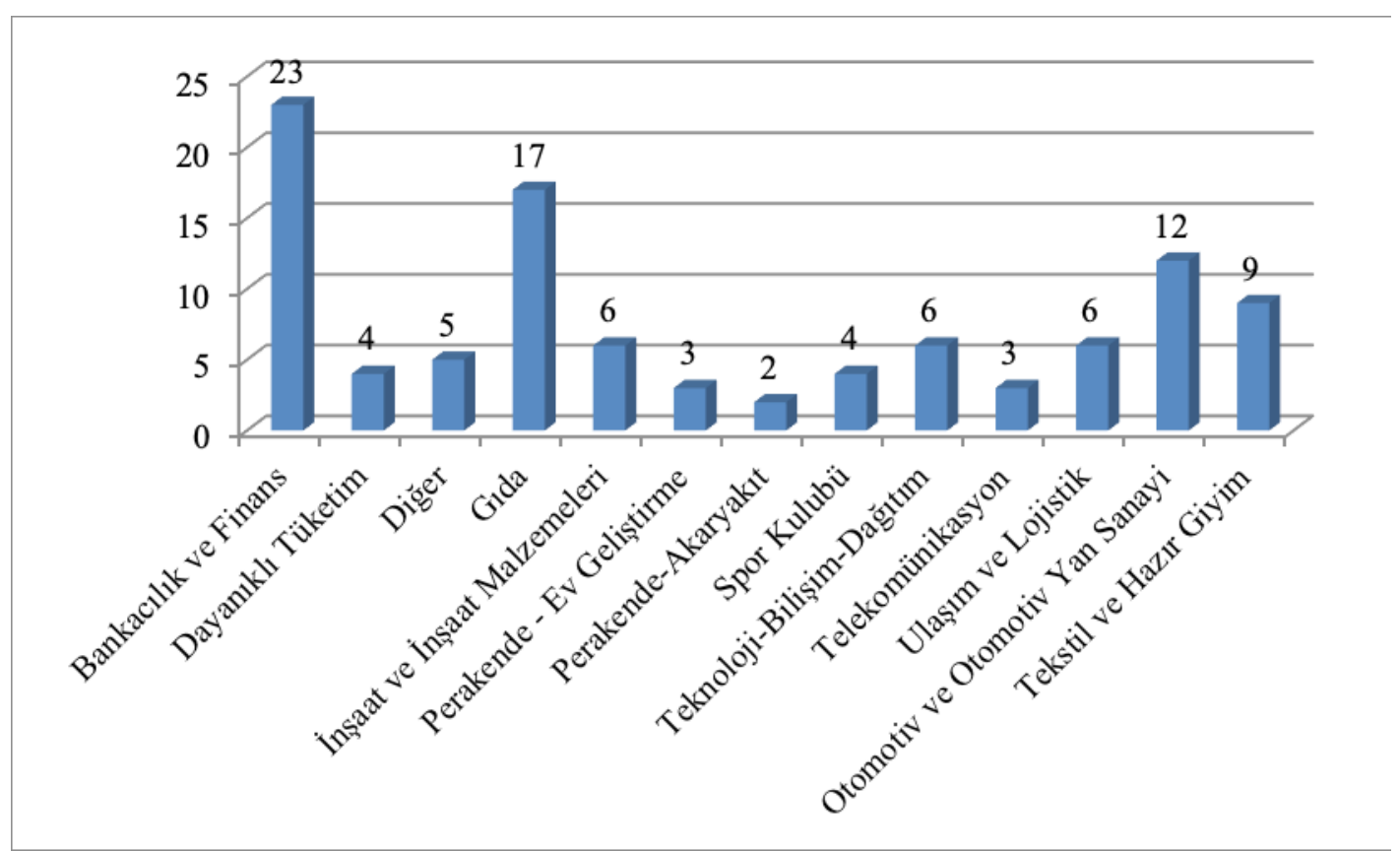

Şekil 1: En Değerli 100 Markanın Sektörlere Göre Dağılımı

Sosyal medya kullanımının pazarlama üzerindeki etkisini ortaya koyabilmek için öncelikli olarak yapılması gereken, sektörlerin önde gelen markalarının sosyal medyadaki etkinliklerinin tespit edilmesidir. $\mathrm{Bu}$ amaçla markaların sosyal medya takipçi sayıları incelenmiştir. Tablo 2 Türkiye'de marka değeri en yüksek 100 firmanın sektörlere göre sosyal medyadaki takipçi sayılarını göstermektedir. 
Tablo 2: Sektörlere Göre Sosyal Medyadaki Toplam Takipçi Sayıları

\begin{tabular}{|l|c|c|c|c|c|c|c|}
\hline SEKTÖR GRUP & Instagram & Facebook & Twitter & Linkedln & Youtube & Pinterest & $\begin{array}{c}\text { Toplam } \\
\text { Takipçi Sayısı }\end{array}$ \\
\hline Bankacılık ve Finans & 438.964 & 11.003 .854 & 1.839 .438 & 551.835 & 189.840 & 8 & 14.023 .939 \\
\hline Dayanıkı Tüketim & 150.613 & 1.940 .064 & 134.429 & 231.533 & 40.421 & 232 & 2.497 .292 \\
\hline Diğer & 139.871 & 2.817 .596 & 4.364 .325 & 256.444 & 13.329 & 101 & 7.591 .666 \\
\hline Gıda & 527.828 & 5.431 .721 & 564.001 & 209.972 & 29.945 & 147 & 6.763 .614 \\
\hline $\begin{array}{l}\text { İnşaat ve Inş̧aat } \\
\text { Malzemeleri }\end{array}$ & 7.600 & 259.913 & 4.103 & 139.917 & 1.531 & 68 & 413.132 \\
\hline $\begin{array}{l}\text { Otomotiv ve } \\
\text { Otomotiv Yan Sanayi }\end{array}$ & 142.098 & 10.826 .107 & 505.468 & 497.522 & 61.034 & - & 12.032 .229 \\
\hline $\begin{array}{l}\text { Perakende - Ev } \\
\text { Geliştirme }\end{array}$ & 584.472 & 1.404 .891 & 83.698 & 17.026 & 21.502 & 1.103 & 2.112 .692 \\
\hline Perakende-Akaryakıt & 55.299 & 1.241 .029 & 23.986 & 27.241 & 8.546 & 14 & 1.356 .115 \\
\hline Spor Kulübü & 9.111 .214 & 27.762 .215 & 19.420 .754 & 17.355 & 634.590 & 10.194 & 56.956 .322 \\
\hline $\begin{array}{l}\text { Teknoloji-Bilişim- } \\
\text { Dağıtım }\end{array}$ & 164.607 & 2.976 .464 & 637.615 & 53.396 & 38.739 & 787 & 3.871 .608 \\
\hline Tekstil ve Hazır Giyim & 3.203 .464 & 4.494 .836 & 340.738 & 119.330 & 37.883 & 7.521 & 8.203 .772 \\
\hline Telekomünikasyon & 107.124 & 6.397 .727 & 1.103 .167 & 149.782 & 319.201 & - & 8.077 .001 \\
\hline Ulaşım ve Lojistik & 1.210 .307 & 12.349 .998 & 2.092 .663 & 398.359 & 227.776 & 316 & 16.279 .419 \\
\hline Genel Toplam & 15.843 .461 & 88.906 .415 & 31.114 .385 & 2.669 .712 & 1.624 .337 & 20.491 & 140.178 .801 \\
\hline
\end{tabular}

Toplam takipçi sayısı en yüksek olan sektör 56.956.322 ile spor kulüpleridir. Ulaşım ve lojistik sektörü ise 16.279.419 ile ikinci sıradadır. İnşaat ve İnşaat Malzemeleri sektörü ise en az takipçisi olan sektördür. Bu üç sektör de tüm sosyal medya platformlarında yer almaktadır.

100 markanın tamamı dikkate alındığında en fazla kullanıldığı belirlenen 6 farklı sosyal medya platformunun kullanım oranlarının dağılımı Şekil 2'de gösterildiği gibidir.

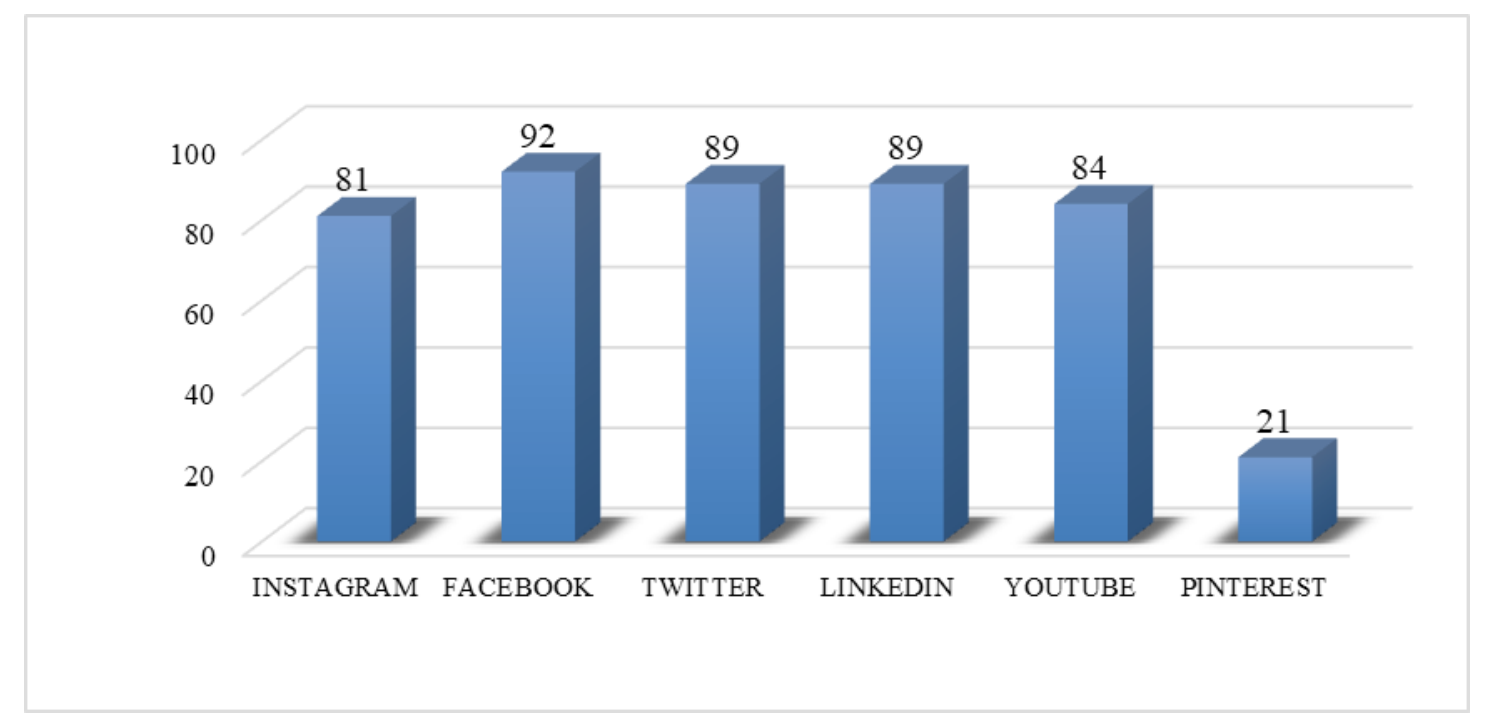

Şekil 2: Türkiye'de Marka Değeri En Yüksek 100 Firmanın Sosyal Medya Kullanımının Dağılımı

Şekil 2 incelendiğinde 100 markanın 92 tanesinin Facebook hesabı bulunduğu görülmektedir. LinkedIn ve Twitter sosyal medya platformlarına bakıldığında ise yüz şirketten 89'unun hesabı bulunmaktadır. Bu 100 şirketten sadece 21 tanesinin Pinterest hesabı vardır. Bu verilere göre Facebook ilk sırada, Pinterest son sırada kullanılan sosyal medya platformu olarak karşımıza çıkmaktadır. 
Çalışmanın iki temel amacı bulunmaktadır. $\mathrm{Bu}$ amaçla yapılacak testlerin belirlenmesi için verilere normallik testi uygulanmıştır. Yapılan normallik testleri sonucu toplanan verilerin normal dağıldığı görülmüştür.

Marka değeri ile takipçi sayısı arasındaki ilişkileri tespit etmek amacıyla kurulan hipotez aşağıda yer almaktadır.

$\mathrm{H}_{1}=$ Marka değeri ve sosyal medya takipçi sayıları arasında istatistiksel olarak anlamlı bir ilişki vardır.

Bu hipotezi test etmek amacıyla yapılan korelasyon analizi sonuçları aşağıda Tablo 3'de görülmektedir.

Tablo 3: Marka Değeri ile Toplam Takipçi Sayısı Arasındaki İlişsi

\begin{tabular}{|l|l|l|}
\hline \multicolumn{3}{|c|}{ Marka Değeri } \\
\hline \multirow{3}{*}{$\begin{array}{l}\text { Toplam Takipçi } \\
\text { Sayısı }\end{array}$} & Pearson Correlation &, $240^{*}$ \\
\cline { 2 - 3 } & Sig. (2-tailed) &, 016 \\
\cline { 2 - 3 } & $\mathrm{n}$ & 100 \\
\hline
\end{tabular}

Marka değerini oluşturan faktörlerden bir tanesi de tüketici temelli marka denkliğidir. Literatürde sosyal medya faaliyetlerinin marka denkliği ile pozitif yönde ilişkili olduğu görülmektedir. Buna göre marka değeri ile sosyal medya faaliyetleri arasında pozitif yönlü ilişki bulunması beklenmektedir. Analiz sonucuna göre marka değeri ile sosyal medyada takipçi sayıları arasında istatistiksel olarak anlamlı pozitif yönde bir ilişki tespit edilmiştir.

Marka değeri ile farklı sosyal medya platfomları takipçi sayıları ile arasındaki ilişkileri tespit etmek amacıyla kurulan hipotez aşağıda yer almaktadır.

$\mathrm{H}_{2}=$ Marka değeri ve farklı sosyal medya platfomları takipçi sayıları arasında istatistiksel olarak anlamlı bir ilişki vardır.

Bu hipotezi test etmek amacıyla yapılan korelasyon analizi sonuçları aşağıda Tablo 4'te görülmektedir.

Tablo 4: Marka Değeri ve Farklı Sosyal Medya Platfomları Takipçi Sayıları Arasındaki İlişki

\begin{tabular}{|l|c|c|c|c|c|c|}
\hline $\begin{array}{l}\text { Marka } \\
\text { Değeri }\end{array}$ & Instagram & Facebook & Twitter & LinkedIn & Youtube & Pinterest \\
\hline $\begin{array}{l}\text { Pearson } \\
\text { Correlation }\end{array}$ &, 015 &, $372^{\star *}$ &, 034 &, $525^{\star *}$ &, $463^{\star *}$ &,- 078 \\
\hline $\begin{array}{l}\text { Sig. } \\
(2-\text { tailed })\end{array}$ &, 881 &, 000 &, 736 &, 000 &, 000 &, 443 \\
\hline $\mathrm{n}$ & 100 & 100 & 100 & 100 & 100 & 99 \\
\hline
\end{tabular}

Marka değeri ve sosyal medya platformu takipçi sayıları arasındaki ilişki incelendiğinde facebook, linkedIn ve youtube platformlarının, firmaların marka değeri ile istatistiksel olarak anlamlı pozitif yönde ilişkili oldukları görülmektedir.

Marka değeri ile takipçi sayıları ile arasındaki farklılıkları tespit etmek amacıyla kurulan hipotez aşağıda yer almaktadır.

$\mathrm{H}_{3}=$ Marka değeri ve takipçi sayıları arasında istatistiksel olarak anlamlı bir farklılık vardır. 
Bu hipotezi test etmek amacıyla yapılan Tek Yönlü Varyans (ANOVA) analizi sonuçları aşağıda Tablo 5'te görülmektedir.

Tablo 5: Marka Değeri ve Takipçi Sayıları Grupları Arasındaki Farklılık

\begin{tabular}{|c|c|c|c|c|c|c|}
\hline \multirow{2}{*}{\multicolumn{2}{|c|}{ Takipçi Sayısı }} & \multirow{3}{*}{$\begin{array}{c}\text { Ortalama Fark } \\
-, 785\end{array}$} & \multirow{3}{*}{$\begin{array}{c}\text { Standart Hata } \\
, 348\end{array}$} & \multirow{3}{*}{$\begin{array}{c}\mathbf{p} \\
, 115\end{array}$} & \multicolumn{2}{|c|}{ Aralık } \\
\hline & & & & & \multirow{2}{*}{$\begin{array}{c}\text { Alt Sinır } \\
-1,69\end{array}$} & \multirow{2}{*}{$\begin{array}{c}\text { Üst Sınır } \\
, 12\end{array}$} \\
\hline \multirow{3}{*}{$0-10.000$} & $\begin{array}{l}10.001- \\
100.000\end{array}$ & & & & & \\
\hline & $\begin{array}{l}100.001- \\
1.000 .000\end{array}$ &,- 551 & ,324 & ,331 & $-1,40$ & ,30 \\
\hline & $\begin{array}{l}1.000 .001 \\
\text { ve üstü }\end{array}$ & $-1,837$ & ,345 & ,000 & $-2,74$ &,- 93 \\
\hline \multirow{3}{*}{$\begin{array}{l}10.001- \\
100.000\end{array}$} & $0-10.000$ & ,785 & ,348 & ,115 &,- 12 & 1,69 \\
\hline & $\begin{array}{l}100.001- \\
1.000 .000\end{array}$ & ,235 & 263 & 809 &,- 45 & ,92 \\
\hline & $\begin{array}{l}1.000 .001 \\
\text { ve üstü }\end{array}$ & $-1,052$ & 289 & ,002 & $-1,81$ &,- 30 \\
\hline \multirow{3}{*}{$\begin{array}{l}100.001- \\
1.000 .000\end{array}$} & $0-10.000$ & ,551 & ,324 & ,331 &,- 30 & 1,40 \\
\hline & $\begin{array}{l}10.001- \\
100.000\end{array}$ &,- 235 & ,263 & ,809 &,- 92 & ,45 \\
\hline & $\begin{array}{l}1.000 .001 \\
\text { ve üstü }\end{array}$ & $-1,286$ & 260 & ,000 & $-1,97$ &,- 61 \\
\hline \multirow{3}{*}{$\begin{array}{l}1.000 .001 \\
\text { ve üstü }\end{array}$} & $0-10.000$ & 1,837 & ,345 & ,000 & ,93 & 2,74 \\
\hline & $\begin{array}{l}10.001- \\
100.000\end{array}$ & 1,052 & 289 & ,002 & ,30 & 1,81 \\
\hline & $\begin{array}{l}100.001- \\
1.000 .000\end{array}$ & 1,286 & ,260 & ,000 & ,61 & 1,97 \\
\hline \multicolumn{7}{|c|}{$\mathrm{F}=12,172$} \\
\hline
\end{tabular}

Verilerin varyanslarının homojen olup olmadığı Levene istatistiği ile test edilmiş, varyansların homojen olduğu görülmüştür. Tablo 5 'te yer alan analizinin sonucuna göre bulunan Anova modeli anlamlıdır ( $F=12,172, p<0,001)$. Buna göre marka değeri ile takipçi sayısı arasında istatistiksel olarak anlamlı bir farklılık vardır. Çoklu karşılaştırma Tukey analizine göre marka değeri ile takipçi sayısı arasında tespit edilen farklılığın 1.000.001 ve üstü takipçi sayısı olan firmalardan kaynaklandığı görülmüştür. 1.000.001 ve üstü ve diğer takipçi sayıları grupları arasındaki fark pozitif çıkmıştır. Ortalama fark değeri pozitif çıktığı için 1.000 .000 ve üzeri takipçi sayısı olan firmaların marka değeri ortalamalarının diğer takipçi sayısı gruplarına göre daha yüksek olduğu söylenebilir.

Sektörel marka değeri ile takipçi sayıları arasındaki farklılıkları tespit etmek amacıyla kurulan hipotez aşağıda yer almaktadır.

$\mathrm{H}_{4}=$ Sektörlerin marka değeri ve takipçi sayıları arasında istatistiksel olarak anlamlı bir farklılık vardır.

Firmaların sektörler itibariyle toplam takipçi sayıları arasındaki farklılıkların tespit edilmesi amacıyla uygulanan Tek Yönlü Varyans analizinde varyansların homojen olduğu görülmüştür. 
Tablo 6: Sektörler ve Takipçi Sayıları Grupları Arasındaki Farklılık

\begin{tabular}{|c|c|c|c|c|c|c|}
\hline \multirow{2}{*}{\multicolumn{2}{|c|}{ Takipçi Sayısı }} & \multirow{3}{*}{$\begin{array}{c}\text { Ortalama Fark } \\
13.629 .344\end{array}$} & \multirow{3}{*}{$\begin{array}{c}\text { Standart Hata } \\
1.403 .096\end{array}$} & \multirow{3}{*}{$\begin{array}{c}\mathbf{p} \\
, 000\end{array}$} & \multicolumn{2}{|c|}{ Aralık } \\
\hline & & & & & \multirow{2}{*}{$\begin{array}{c}\text { Alt SInır } \\
8.849 .520\end{array}$} & \multirow{2}{*}{\begin{tabular}{|c|} 
Üst Sınır \\
18.409 .168 \\
\end{tabular}} \\
\hline \multirow{13}{*}{$\begin{array}{l}\text { Spor } \\
\text { Kulübü }\end{array}$} & $\begin{array}{l}\text { Bankacillk } \\
\text { ve Finans }\end{array}$ & & & & & \\
\hline & Dayanıkı Tüketim & 13.614 .758 & 1.831 .405 & ,000 & 7.375 .844 & 19.853 .671 \\
\hline & Gıda & 13.841 .221 & 1.439 .311 & ,000 & 8.938 .026 & 18.744 .416 \\
\hline & $\begin{array}{l}\text { İnşaat ve İnşaat } \\
\text { Malzemeleri }\end{array}$ & 14.170 .225 & 1.671 .836 & ,000 & 8.474 .903 & 19.865 .548 \\
\hline & $\begin{array}{l}\text { Perakende - Ev } \\
\text { Geliştirme }\end{array}$ & 13.534 .850 & 1.978 .143 & ,000 & 6.796 .053 & 20.273 .646 \\
\hline & $\begin{array}{l}\text { Perakende- } \\
\text { Akaryakıt }\end{array}$ & 13.561 .023 & 2.243 .004 & ,000 & 5.919 .946 & 21.202 .100 \\
\hline & $\begin{array}{l}\text { Teknoloji-Bilişim- } \\
\text { Dağıtım }\end{array}$ & 13.593 .813 & 1.671 .836 & ,000 & 7.898 .490 & 19.289 .135 \\
\hline & Telekomünikasyon & 11.546 .747 & 1.978 .143 & ,000 & 4.807 .950 & 18.285 .543 \\
\hline & Ulaşım ve Lojistik & 11.525 .844 & 1.671 .836 & , 000 & 5.830 .521 & 17.221 .167 \\
\hline & $\begin{array}{l}\text { Otomotiv ve } \\
\text { Otomotiv Yan } \\
\text { Sanayi }\end{array}$ & 13.236 .395 & 1.495 .336 & , 000 & 8.142 .343 & 18.330 .446 \\
\hline & $\begin{array}{l}\text { Tekstil ve } \\
\text { Hazır Giyim }\end{array}$ & 13.327 .550 & 1.556 .395 &, 000 & 8.025 .493 & 18.629 .607 \\
\hline & Diğer & 12.720 .747 & 1.737 .423 & ,000 & 6.801 .994 & 18.639 .500 \\
\hline & & $F=9,059$ & $\mathrm{p}=, 000$ & & & \\
\hline
\end{tabular}

Tablo 6'da yer alan Tek Yönlü Varyans (ANOVA) analizinin sonucuna göre marka değeri ile takipçi sayısı arasında $(\mathrm{p}<0,05)$ istatistiksel olarak anlamlı bir farklılık vardır. Çoklu karşılaştırma Tukey analizine göre sektörler ile takipçi sayısı arasında tespit edilen farklılığın Spor kulüpleri sektöründen kaynaklandığı görülmüştür.

Çalışmanın bir diğer amacı bağımlı değişken marka değerindeki değişimin ne kadarının bağımsız değişken sosyal medya platformlarındaki takipçi sayıları ile açıklandığıdır. Bu amaçla yapılan regresyon analizinin sonucu Tablo 7'de yer almaktadır.

Tablo 7: Regresyon Analizi Sonuçları

\begin{tabular}{|c|c|c|c|c|}
\hline \multirow{2}{*}{\multicolumn{2}{|c|}{ Marka değeri }} & Beta Katsayıları & t Değeri & Anlamlılık Düzeyi \\
\hline & & ,240 & 2,446 &, 016 \\
\hline$R=, 240$ & $R^{2}=, 058$ & lanmış $R^{2}=, 048$ & $F=5,984$ & mlılık Düzeyi=,016 \\
\hline
\end{tabular}

$\mathrm{Bu}$ analize göre marka değeri ile takipçi sayıları arasındaki ilişki istatistiksel olarak anlamlı bulunmuştur $(\mathrm{p}<0,05)$. Tabloda modelde yer alan marka değerinin standart beta katsayısı, t değeri ve önem düzeyi verilmiştir. Değișkenler arasında pozitif yönlü zayıf bir ilişki vardır ( $\mathrm{r}=0,240)$. Belirlilik katsayısı $\left(\mathrm{R}^{2}\right)$ 0,048 olarak hesaplanmış olup marka değerindeki değişimlerin \% 4.8'inin sosyal medya takipçi sayısına bağlı olduğu söylenebilir. Bu sonuçlara göre, bir markanın takipçi sayısı arttıkça marka değerinin de artacağı söylenebilir. Bu durumun tersi de mümkündür.

\section{Sonuç ve Değerlendirme}

Günümüzdeki teknolojik gelişmelerin, internet ve sosyal medya kullanımındaki artışın, küreselleșmenin, artan müşteri değeri ve müşteri ilişkilerinin pazarlamanın geleceğine yön verdiği görülmektedir. İnternetin gelişmesiyle birlikte iletişimde 
dijitalleşmenin önemi gün geçtikçe artmaya başlamıştır. Web 2.0 devrimi ile sosyal medya platformları ortaya çıkmıştır. Sosyal medyanın iletişim alanında yarattığı fayda, karşılıklı etkileșim ve iletişimi mümkün hale getirmektedir. Sosyal medya kullanıcı sayısının hızlı bir şekilde artması ile markalar için bu mecra yeni pazarlama kanalları olarak düşünülmeye başlanmıștır. Zamanla sosyal medya, hedef tüketici ile doğrudan iletişim kurmaya, marka tanınırlığını arttırmaya ve yeni ürünler için bir pazar yeri görevi görmeye başlamıștır. Sosyal medya hesapları, işletmeler ve markalar için vazgeçilmez bir iletişim kanalı halini almıştır. Sosyal medya ortamları, bireylerin çevrimiçi sosyal ağlar aracılığı ile kendi web sitelerini, ürünlerini ya da hizmetlerini geleneksel reklam kanalları ile mümkün olamayacak kadar büyük topluluklara ulaşıp tanıtmalarına, onlarla iletişim kurmalarına olanak verebilmektedir (Mucuk, 2013, 13). Facebook, Instagram, Twitter, Pinterest, LinkedIn, Youtube gibi sosyal ağlar üzerinden yürütülen pazarlama faaliyetleri giderek önem kazanmaktadır. Sosyal medya hesapları üzerinden yapılacak pazarlama faaliyetlerinin başarıya ulaşması için, tüm sosyal medya kanallarında hesaplar açılmall, hesapların etkin, verimli ve güncel olarak kullanılması gerekmektedir.

Brand Finance araştırma şirketinin 2017 yılı için belirlediği Türkiye'nin marka değeri en yüksek 100 firması üzerinde yapılan çalışmada, sosyal medya platformlarının firmalar tarafından kullanımları ve sektörlere göre dağılımları incelenmiştir. Firmaların sosyal medya kullanımlarını etkileyen etkenlerden biri müşteri ile olan doğrudan temaslarıdır. Bankacılık, Moda ve Hazır Giyim, Spor, Otomotiv, Gıda, Medya gibi sektörlerin müşteri ile doğrudan temas kurması nedeniyle sosyal medyayı daha aktif kullandıkları ve takipçi sayılarının daha fazla olduğu görülmektedir. İnşaat, Yapı, Savunma, Enerji sektörleri gibi müşteri ile doğrudan teması bulunmayan sektörlerde firmalar sosyal medyayı sınırlı olarak kullanmaktadır.

Araştırmanın sonucunda 2017 Aralık ayı itibari ile Türkiye'deki firmalar tarafından en çok kullanılan sosyal medya platformunun Facebook olduğu tespit edilmiştir. İkinci sırada Twitter gelmektedir. Sonrasında sırasıyla LinkedIn, Youtube, Instagram ve Pinterest bulunmaktadır. Sosyal medya platformları arasında gerek kullanım gerekse takipçi sayıları açısından Facebook, Twitter ve LinkedIn'in ilk üç sırada yer almasında bu platformların video, görüntü ve metin paylaşımına imkan vermesinin etkili olduğu söylenebilir. Marka değeri ve sosyal medya platformu takipçi sayıları arasındaki ilişki incelendiğinde Facebook, Linkedin ve Youtube platformlarının, firmaların marka değeri ile istatistiksel olarak anlamlı pozitif yönde ilişkili oldukları görülmektedir. 2018'in ikinci çeyreği itibarıyla Facebook'un aylık aktif kullanıcı sayısı 2,23 milyar kişiye ulaşmıştır (www.statista.com; Erişim: 25/08/2018). Facebook ulaştığı bu büyük kitle ile işletmelerin pazarlama çabalarında çok büyük fırsatlar yaratabilme potansiyeline sahiptir.

Instagram, daha çok görsel paylaşımların takip edildiği bir platformdur. Firmalar bu platformu gerek tanıtım gerekse pazarlama aracı olarak kullanmaktadır. Rakamlara bakıldığında Instagram'ın müşteri ile doğrudan teması olan firmalar tarafından tercih edildiği ve takip edildikleri görülmektedir. İnşaat, Savunma ve enerji gibi sektörler her ne kadar marka değeri yüksek firmalar olsalar da Instagram kullanmayı tercih etmemektedirler. LinkedIn ise, tanıtım ve pazarlamadan daha çok, insan kaynakları noktasında hem şirketlere hem de çalışanlara hizmet sunmasından dolayı tercih edildiğini göstermektedir. Youtube aslında bir sosyal medya platformu değil, video paylaşım sitesidir. Ancak kullanıcılarına kanal açma fırsatı sunduğu için bir tanıtım 
ve pazarlama aracı olarak da kullanılmaktadır. Youtube kanallarının özellikle spor sektöründe etkin olarak kullanıldığı, spor sektörü dışındaki firmalar tarafından da reklam ve tanıtım amacıyla kullanıldığı görülmektedir. Pinterest görsel bir sosyal medya platformudur. Paylaşımlar daha çok fotoğraflara dayanır ve firmalar tarafından çok fazla kullanılmamaktadır. Sosyal medya platformlarının firmalar tarafından kullanım oranları göz önünde bulundurulduğunda, kullanıcılarına sunduğu imkanların firmaların tercihlerini etkilediği görülmektedir. Hem video/ görüntü hem de metin paylaşımına izin veren platformlar daha çok tercih edilirken, Pinterest gibi ağırlıklı olarak görüntü paylașımı sağlayan sosyal medya platformları diğer platformlara göre daha az tercih edilmektedir. Firmaların sosyal medya platformlarını tercih sebebi ve bu platformlardaki takipçi sayılarının, söz konusu sosyal medya platformlarının genel kullanım oranlarıyla paralellik gösterdiği ifade edilebilir. Türkiye'de en çok kullanılan sosyal medya platformlarının, firmalar tarafından da benzer sıra ile tercih edildiği görülmektedir.

Firmaların birbirinden farklı sektörlerde faaliyet göstermeleri, tüm sektörlerde eşit sayıda firmanın bulunmayışı, sektörleri temsil eden firmaların yalnızca Brand Finance şirketinin yayınladığı liste ile sınırlı tutulması araştırmanın temel kısıtlarındandır. Araștırmanın bir diğer kısıtı ise sosyal medya faaliyetleri incelenirken sadece takipçi sayılarının dikkate alınmasıdır. Bununla birlikte bu araștırma, genel olarak sektörlerin sosyal medya platformlarını kullanımlarına dair önemli tespitler içermektedir. Gelecek çalışmalarda sosyal medya ile ilgili daha detaylı metrikler araştırmaya dahil edilebilir.

Sosyal medya bu yüzyılda, iletişim kurmanın yeni bir yöntemi haline gelmiştir. Twitter, Facebook ve Linkedln gibi sosyal medya araçlarının büyüme hızı, dünyayı yeni bir sosyal medya çağına dönüştürmüştür. Doğru planlanmış bir sosyal medya stratejisi uygulandığında bu iletişim türünün işletmeler üzerinde de büyük bir etkisi olacaktır. Sosyal medya markaların tüketicileriyle daha iyi iletişim kurmasını ve onlarla ilişkilerini yoğunlaştırmasını sağlamaktadır. Sosyal medya, pazarlama yöneticileri açısından pazar payını artırmak için de büyük bir fırsat olarak görülmektedir. Ancak sosyal medyanın sunduğu firsatlar bundan çok daha fazladır. Şirketlerin yeni ve daha geniş tüketici kitlesine ulaşabilmesine, marka imajı oluşturmasına, işletmenin ya da markanın itibarını arttırmasına, marka denkliğini ve değerini geliştirmesine ve müşteri sadakatini artırmasına imkan tanımaktadır. Çalışmada marka değeri ile sosyal medyada takipçi sayıları arasında istatistiksel olarak anlamlı pozitif yönde bir ilişki tespit edilmiştir. Sosyal medya takipçi sayıları azaldığında, firma değerindeki olası azalışların erken uyarılarına işaret edebilir. Bu açıdan işletmeler bu mecralara daha çok önem vermelidirler. Sosyal medyada başarılı bir katılımı garantilemek için şirketlerin farklı pazarlama teorilerini dikkate almaları ve markalarını farklı açlardan geliştirebilmeleri gerekmektedir. Bunu yapan şirketler sosyal medya pazarlamasında lider olma şansına sahip olurlar. Geleneksel medya kanalları aracılığıyla tüketiciye etkin ulaşmanın zorlaştığı, maliyetlerin de arttığı günümüz pazarlamasında, büyük kitlelere ulaşabilme amacıyla sosyal medya kanalları etkin bir şekilde kullanılabilmelidir. Firmalar sosyal medya stratejilerini net olarak ortaya koyup, bu faaliyetleri planlı bir şekilde yürütmelidir. 


\section{Kaynakça}

Aaker, D. (1991). Brand equity. La gestione del valore della marca, 347-356.

Aaker, D. A. (1992). The value of brand equity. Journal of business strategy, 13(4), 27-32.

Aaker, D. A. (2001). Strategic market management. New York: John Wiley

Aggarwal, R., Gopal, R., Sankaranarayanan, R., ve Singh, P. V. (2012). Blog, blogger, and the firm: Can negative employee posts lead to positive outcomes?. Information Systems Research, 23(2), 306-322.

Alexander, B. (2006). Web 2.0: A New Wave of Innovation for Teaching and Learning, Educase Review, 33-44.

Baldauf, A., Cravens, K. S., ve Binder, G. (2003). Performance consequences of brand equity management: evidence from organizations in the value chain. Journal of product \& brand management, 12(4), 220-236.

Bambauer-Sachse, S. ve Mangold, S. (2011). Brand equity dilution through negative online word-of-mouth communication. Journal of Retailing and Consumer Services, 18(1), 38-45.

Berger Paul, D., Pooja M., Black J.E. ve Jiangmei C. (2012). The Impact of Social Media Usage on Consumer Buying Behavior. Advances in Management, 5 (1), 14-22.

Berthon, P.R., Pitt, L. F., Plangger, K. ve Shapiro, D. (2012). Marketing Meets Web 2.0, Social Media, And Creative Consumers: Implications For International Marketing Strategy. Business Horizons, 55(3), 261-271.

Bruhn, M., Schoenmueller, V., ve Schäfer, D. B. (2012). Are social media replacing traditional media in terms of brand equity creation? Management Research Review, 35(9), 770-790.

Chevalier, J. A., ve Mayzlin, D. (2006). The effect of word of mouth on sales: Online book reviews. Journal of marketing research, 43(3), 345-354.

Cobb-Walgren, C. J., Ruble, C. A. ve Donthu, N. (1995). Brand equity, brand preference, and purchase intent. Journal of advertising, 24(3), 25-40.

Constantinides, E. ve Fountain, S. J. (2008). Web 2.0: Conceptual Foundations and marketing issues. Journal of direct, Data and Digital Marketing Practice, 9 (3), 231-244.

Dellarocas, C., Zhang, X. ve Awas, N. (2007). Exploring the value of online product reviews in foreasting sales: the case of motion pictures. Journal of Interactive Marketing, 21 (4), 23-45.

Dewan, S., ve Ramaprasad, J. (2012). Research note Music blogging, online sampling, and the long tail. Information Systems Research, 23(3-part-2), 1056-1067.

Dhar, V. ve Chang E.A. (2009). Does Chatter Matter? The Impact of User-Generated Content on Music Sales. Journal of Interactive Marketing, 23, 300-307.

Divol, R., Edelman, D., ve Sarrazin, H. (2012). Demystifying social media. McKinsey Quarterly, 2(12), 66-77. 
Droge, C., Stanko, M. A. ve Pollitte, W. A. (2010). Lead users and early adopters on the web: The role of new technology product blogs. Journal of Product Innovation Management, 27, 66-82.

Duan, W., Gu, B., ve Whinston, A. B. (2008). Do online reviews matter? - An empirical investigation of panel data. Decision Support Systems, 45(4), 1007-1016.

Farquhar, P. H., Han, J. Y., ve Ijiri, Y. (1991). Recognizing and measuring brand assets. Report/Marketing Science Institute (USA).

Gallaugher, J., ve Ransbotham, S. (2010). Social media and customer dialog management at Starbucks. MIS Quarterly Executive, 9(4).

Gao, G., ve Hitt, L. M. (2012). Information technology and trademarks: Implications for product variety. Management Science, 58(6), 1211-1226.

Gensler, S., Völckner, F., Liu-Thompkins, Y. ve Wiertz, C. (2013).Managing Brands In The Social Media Environment. Journal Of Interactive Marketing, 27(4), 242256.

Ghose A. ve Yang S. (2009). An empirical analysis of search engine advertising: Sponsored search in electronic markets. Management Sci. 55(10),1605-1622.

Godes, D. B. ve Mayzlin, D.. (2004). Using online conversation to study word-ofmouth communication. Marketing Sci. 23(4), 545-560.

Goh, K.Y., Heng, C.S. ve Lin, Z. (2013). Social Media Brand Community and Consumer Behavior: Quantifying The Relative Impact Of User-and Marketer Generated Content. Information Systems Research, 24(1), 88-107.

Güler, K. (2015). Social Media-Based Learning In The Design Studio: A Comparative Study. Computers \& Education, , 87, 192-203.

Gümüş, N., Zengin H. ve Geçti F. (2013). Sosyal Medya Aracı Olarak Facebook Uygulamalarının Marka Denkliği Üzerindeki Etkisi: Bir Gsm Operatörünün Facebook Sayfası Üzerinde Araştırma. Sakarya İktisat Dergisi, 2 (6), 87-117.

Haigh D. ve İlgüner M. (2012). Marka Değeri. Markating Yayınları, 1. Basım, İstanbul.

Hayta, A.B. (2013). A Study on the of Effects of Social Media on Young Consumers' Buying Behaviors. European Journal of Research on Education, Special Issue: Human Resource Management: Special Issue, 65-74.

Huang, J. (2015). A review of brand valuation method. Journal of service science and management, 8(1), 71-76.

Huang, Z., ve Benyoucef, M. (2013). From e-commerce to social commerce: A close look at design features. Electronic Commerce Research and Applications, 12(4), 246-259.

Huang, Z., ve Benyoucef, M. (2015). User preferences of social features on social commerce websites: An empirical study. Technological Forecasting and Social Change, 95, 57-72.

Jones, R. (2005). Finding sources of brand value: Developing a stakeholder model of brand equity. Journal of brand management, 13(1), 10-32.

Kapferer, J. N. (1997). Managing luxury brands. Journal of brand management, 4(4), 251-259. 
Kaplan, A.M. ve Haenlein, M. (2010). Users of the world, unite! The challenges and opportunities of Social Media. Business horizons, 53(1), 59-68.

Kara, T. (2012). Sosyal medya üzerinde yeni nesil pazarlama ve türkiye bilgi \& iletişim hizmetleri endüstrisinde sosyal ağların kullanımına yönelik bir araştırma. Global Media Journal: Turkish Edition, 2 (4), 102-117.

Kazancı, Ş. ve Başgöze, P. (2015) Sosyal Medya Algısının, Marka Kredibilitesinin Ve Marka Prestijinin Satın Alma Eğilimi Üzerine Etkileri. Ankara Üniversitesi SBF Dergisi, 70(2), 435-456.

Keller, K. L. (1993). Conceptualizing, measuring, and managing customer-based brand equity. the Journal of Marketing, 1-22.

Kim, A. J. ve Ko, E. (2012). Do social media marketing activities enhance customer equity? An empirical study of luxury fashion brand. Journal of Business Research, 65(10), 1480-1486.

Kotler, P. (2010). Pazarlama 3.0. Baskı 2, Optimist Yayınları, İstanbul.

Larivière, B., Joosten, H., Malthouse, E.C., Van Birgelen, M., Aksoy, P., Kunz, W.H. ve Huang, M.H. (2013). Value Fusion: The Blending Of Consumer and Firm Value In The Distinct Context Of Mobile Technologies and Social Media. Journal of Service Management, 24(3), 268-293.

Li, C. ve Bernoff, J. (2011) Groundswell: Winning in a world transformed by social technologies. Boston M.A.: Harvard Business Review Press.

Liu, Y. (2006). Word of mouth for movies: Its dynamics and impact on box office revenue. Journal of marketing, 70(3), 74-89.

Luo, X., Zhang, J., ve Duan, W. (2013). Social media and firm equity value. Information Systems Research, 24(1), 146-163.

Mangold, W.G. ve Faulds, D.J. (2009). Social media: The new hybrid element of the promotion. Business horizons, 52(4), 357-359.

Moe, W.W. and Fader P.S. (2004). Dynamic Conversion Behavior at E-Commerce Sites. Management Science, 50(3), 326 - 335.

Mucuk İ. (2013). Temel Pazarlama Bilgileri, Türkmen Kitapevi, İstanbul.

O'Keeffe, G.S. ve Clarke-Pearson, K. (2011). The Impact Of Social Media On Children, Adolescents and Families. Pediatrics, 127(4), 800-804.

Özkan, M. ve Terzi, S. (2012). Finansal Raporlama Açısından Marka Değerinin Ölçümü ve Değerlendirmesi, Marmara Üniversitesi Sosyal Bilimler Enstitüsü Hakemli Dergisi Öneri, 10, (38), s.87-96.

Rowlands, I., Nicholas, D., Russell, B., Canty, N. ve Watkinson, A. (2011). Social Media Use In The Research Workflow. Learned Publishing, 24(3), 183-195.

Safko, L. (2010). The Social Media Bible: Tactics, Tools, And Strategies For Business Success. John Wiley \& Sons.

Salinas, G. ve Ambler, T. (2009). A taxonomy ofbrand valuation practice: Methodologies and purposes. Journal of Brand Management, 17(1), 39-61.

Schivinski, B. (2013). Effects of Social Media Communication on Brand Equity and Brand Purchase Intention. Phd Interdisciplinary Journal, 2: 157-162. 
Schivinski, B. ve Dabrowski, D. (2014). The Effect of Social Media Communication on Consumer Perceptions of Brands. Journal of Marketing Communications, (Ahead-ofprint): 1-26.

Simon, C. J. ve Sullivan, M. W. (1993). The measurement and determinants of brand equity: A financial approach. Marketing Science, 12(1), 28-52.

Swait, J., Erdem, T., Louviere, J., ve Dubelaar, C. (1993). The equalization price: A measure of consumer-perceived brand equity. International Journal of Research in Marketing, 10(1), 23-45.

Tosun, N. B. (2014). Marka Yönetimi.(2. Baskı). İstanbul: Beta Yayınları.

Turkey 100 Brand Finance (2017). Turkey 100 Report. Haziran. (Erişim Tarihi: 22/05/2018, http://brandfinance.com/images/upload/turkey_100_2017_ unlocked.pdf)

Vinerean, S., Cetina, I., Dumitrescu, L. ve Tichindelean, M. (2013). The Effects of Social Media Marketing On Online Consumer Behavior. International Journal of Business and Management, 8(14), 66-79.

Wang, C.A., Zhang, 0. M. ve Hann, I.H. (2010). Social Bias In Online Product Ratings: A Quasi-Experimental Analysis. WISE 2010, St. Louis, 1-35.

www.statista.com https://www.statista.com/statistics/264810/number-ofmonthly-active-facebook-users-worldwide/ (Erișim Tarihi: 25/08/2018)

Yates, D. ve Paquette, S. (2011). Emergency Knowledge Management and Social Media technologies: A Case Study Of The 2010 Haitian Earthquake. International Journal of Information Management, 31(1), 6-13.

Yoo, B., Donthu, N. and Lee, S. (2000) An Examination of Selected Marketing Mix Elements and Brand Equity. Journal of the Academy of Marketing Science, 28, 195-211.

Yücel, N. (2013). Müșteri İlişkileri Yönetimi'nde Yeni Bir Anlayıș: Sosyal Müșteri İlișkileri Yönetimi. International Journal of Social Science. 6(1), 1641-1656.

Zhu, F., ve Zhang, X. (2010). Impact of online consumer reviews on sales: The moderating role of product and consumer characteristics. Journal of marketing, 74(2), 133-148. 
